\title{
Factors Associated with Adherence to Immunosuppressive Therapy and Barriers in Asian Kidney Transplant Recipients [Corrigendum]
}

\author{
Ganjali R, Sabbagh MG, Nazemiyan F, et al. The authors apologize for this error.
} Immunotargets Ther. 2019;8:53-62.

The authors have advised that Table 2 on page 57 is incorrect. The correct table is shown below.

Table 2 Immunosuppression Non-Adherence of the Study Sample Measured Based on the BAASIS@ Instrument ( $\mathrm{n=133)}$

\begin{tabular}{|c|c|c|c|}
\hline \multicolumn{2}{|l|}{ Adherence Behavior in Previous 4 Weeks } & \multirow{2}{*}{$\begin{array}{l}\begin{array}{l}N(\%) \\
(n=133)\end{array} \\
26(19.5)\end{array}$} & \multirow{2}{*}{$\begin{array}{l}\text { Total } \\
\text { N (\%) } \\
40(30)\end{array}$} \\
\hline I. Not taking a dose of immunosuppressive medications in the past 4 weeks & Once & & \\
\hline & More than once & $14(10.6)$ & \\
\hline \multirow[t]{2}{*}{ 2. Not taking multiple consecutive doses of immunosuppressive medications in the past 4 weeks } & Once & $14(10.5)$ & \multirow[t]{2}{*}{$22(16.6)$} \\
\hline & More than once & $8(6.1)$ & \\
\hline \multirow{2}{*}{$\begin{array}{l}\text { 3. Taking immunosuppressive medications at least two hours earlier or later than the time indicated } \\
\text { on the dosing administration schedule in the past } 4 \text { weeks }\end{array}$} & Once & $54(40.6)$ & \multirow[t]{2}{*}{$113(86.7)$} \\
\hline & More than once & $59(45.9)$ & \\
\hline \multirow[t]{2}{*}{ 4. Reducing the dosage of immunosuppressive medications on your own initiative in the past 4 weeks } & Once & $14(10.5)$ & \multirow[t]{2}{*}{$21(15.8)$} \\
\hline & More than once & $7(5.3)$ & \\
\hline \multirow[t]{2}{*}{ Sum } & Once & $108(8 \mid .2)$ & \\
\hline & More than once & $88(66.17)$ & \\
\hline 5. Self-rated score on correct administration of $\odot$ immunosuppressive medications (min: 0 , max: 10$)^{a}$ & Non-adherent & $7.72( \pm 1.98)$ & \\
\hline
\end{tabular}

ImmunoTargets and Therapy

Dovepress

\section{Publish your work in this journal}

ImmunoTargets and Therapy is an international, peer-reviewed open access journal focusing on the immunological basis of diseases, potential targets for immune based therapy and treatment protocols employed to improve patient management. Basic immunology and physiology of the immune system in health, and disease will be also covered. In addition, the journal will focus on the impact of management programs and new therapeutic agents and protocols on patient perspectives such as quality of life, adherence and satisfaction. The manuscript management system is completely online and includes a very quick and fair peer-review system, which is all easy to use. Visit http://www.dovepress.com/testimonials.php to read real quotes from published authors. 